\title{
A Conferência de Durban contra o Racismo e a responsabilidade de todos
}

\section{J.A. LINDGREN ALVES*}

"Yo soy yo y mi circunstancia y si no la salvo a ella no me salvo yo"
Ortega y Gasset

\section{Introdução}

Quando os delegados e observadores à terceira conferência contra o racismo organizada pelas Nações Unidas deixaram o recinto em Durban, ainda atordoados com as dificuldades do evento, não podiam imaginar o que se iria passar pouco tempo depois. Sabiam que somente à custa de acomodações e manobras de procedimento haviam conseguido a adoção "consensual” dos documentos finais. Isso já era, ou deveria ser, razão mais do que suficiente para temperar otimismos. De qualquer forma, para eles os resultados tinham tido, sem dúvida, aspectos positivos.

O que os participantes do encontro na África do Sul não podiam prever é que, apenas três dias depois, quando muitos ainda se encontravam em trânsito de retorno, os maiores atentados terroristas da História iriam tornar as dificuldades da Conferência irrisórias e seus documentos finais, como que soterrados nas ruínas do World Trade Center. Jamais poderiam imaginar que, com sua enormidade catastrófica, os golpes de 11 de setembro de 2001 nos Estados Unidos, além de realçarem a aparente irrelevância de desavenças diplomático-discursivas, iriam propiciar a restauração no mundo de um "estado da natureza” hobbesiano, amedrontador em múltiplos sentidos. Esclareça-se, todavia, desde logo, que, ao contrário do que se poderia supor, não se pretende nesse artigo analisar o terrorismo, nem o combate contra ele. O escopo do texto é outro.

É compreensível que os ataques arrasadores, ao deixarem todo o planeta em estado inicialmente catatônico, tenham sufocado possíveis entusiasmos com os 
avanços da recém-encerrada Conferência - menores do que se desejava, mas ainda assim positivos em muitas áreas específicas. Por se relacionarem, de alguma maneira irracional, com problemas observados na negociação dos documentos, não era sequer descabida, num átimo irrefletido, uma associação de idéias entre os aviões-bombas suicidas e certas posturas mantidas ao longo das discussões. Que, depois do Onze de Setembro, tenha-se dado, nos Estados Unidos e todos os demais países, prioridade a medidas antiterroristas era também natural. O que não fez sentido nunca e não faz sentido agora, mais de um ano depois, é encarar a conferência de 2001 contra o racismo como um fato despiciendo, a exemplo das anteriores, destinado ao ostracismo por motivos que lhe são próprios.

As críticas a esse primeiro grande encontro do século são acerbas e freqüentes. Algumas, ideológicas, simplesmente refletem políticas longamente assumidas, que nada parece capaz de alterar. Outras decorrem de irrealismo ingênuo, tendente a desconsiderar a complexidade do evento, ou de um simplismo que o separa das circunstâncias de sua realização. As primeiras críticas, por sua natureza fatalmente reducionista, não procuram, nem aceitariam, qualquer tipo de resposta. As segundas, quando bem-intencionadas, talvez possam ser respondidas com um pouco de reflexão. Afinal, poucos acontecimentos recentes permanecem tão mal compreendidos quanto esse conclave mundial.

Parodiando a imagem de Zuenir Ventura para o ano de $1968,{ }^{1}$ a Conferência de Durban contra o Racismo, em 2001, foi uma "conferência que não terminou”. Na verdade, tendo em conta que toda reunião sobre assunto da esfera social estabelece parâmetros para esforços de longa duração - e aqui estamos mais para a longue durée de Braudel do que para o longo prazo de retorno de alguns investimentos econômicos -, é possível dizer, sem erro, que nenhuma conferência desse tipo efetivamente acaba. É, aliás, por isso que as conferências prevêem outros encontros, destinados a avaliar sua implementação. Contudo, diferentemente das congêneres do final do Século XX, sobre o meio ambiente, os direitos humanos em geral, a população e os direitos da mulher, a primeira conferência do Século XXI, inaugurada em 31 de agosto, quase não teve nem mesmo uma sessão de encerramento. Marcada para terminar na tarde de 7 de setembro, seu desfecho protelado ocorreu depois do tempo previsto para sua duração, na tarde do dia 8. E, para ter seus resultados confirmados pela Assembléia Geral da ONU - ainda assim sem consenso, com dois votos contrários e duas abstenções ${ }^{2}$ - foi preciso que a sessão ordinária de 2001 reconvocasse a Assembléia em período extra-regulamentar, no início de 2002. Seus efeitos permanecem, como é sempre natural, dependente da vontade dos responsáveis políticos e “usuários” sociais.

Tendo partido do autor destas linhas, em 1994, quando membro do principal órgão subsidiário da Comissão dos Direitos Humanos das Nações Unidas, a idéia da convocação de uma conferência mundial contra o racismo contemporâneo para culminar o ciclo de conferências sobre temas globais ao terminar a Guerra Fria, 
estudiosos e militantes do assunto têm-lhe perguntado se os problemas apresentados haviam sido previstos desde o início. A resposta é, certamente, não. Algumas das dificuldades já eram, então, obviamente, intuídas, mas não com a intensidade revelada. Outras se acrescentaram com o tempo ou em função de modificações da idéia original.

\section{As origens da conferência}

Quando a proposta foi lançada na então denominada Subcomissão para a Prevenção da Discriminação e Proteção das Minorias ${ }^{3}$ - que tinha, portanto, até no nome a obrigação prioritária de combater as discriminações - e foi, literalmente, subscrita pela unanimidade menos 1 dos 26 integrantes desse órgão, ${ }^{4}$ sendo adotada por consenso real (não, como se diz na ONU, simplesmente "sem voto”), o mundo vivia momento distinto.

As conferências do Rio de Janeiro, de 1992, sobre o meio ambiente, e de Viena, de 1993, sobre direitos humanos, embora também difíceis, haviam acabado de transcorrer satisfatoriamente. Pareciam, assim, reconfirmar uma nova fase de confiança na diplomacia parlamentar, recém-egressa da chamada "crise do multilateralismo”, muito falada nos anos 80, enquanto perdurava a Guerra Fria. Esse vigor renovado das Nações Unidas como foro imprescindível à busca de soluções para problemas que se demonstravam planetários, em 1994 já lhes havia permitido a definição de um cronograma de encontros sobre os chamados "temas globais” que se estendia até 1996, com a conferência de Istambul sobre assentamentos humanos, a Habitat-II, passando em 1994 pelo Cairo, com o tema da população, e em 1995 por Copenhague, com o desenvolvimento social, e ainda por Pequim, com a situação da mulher. ${ }^{5}$ Era, portanto, natural que a ONU procurasse um caminho novo também para enfrentar a persistência do racismo, que já havia justificado duas "Décadas" internacionais de planos, projetos e programas, sob a égide da Assembléia Geral, assim como duas conferências. E uma Terceira Década de Combate ao Racismo e à Discriminação Racial, lançada pela Resolução 48/91, de 20 de dezembro de 1993, estava então iniciando.

Foi no contexto da Primeira Década que haviam ocorrido as duas conferências precedentes, em 1978 e 1983, ${ }^{6}$ de pequena repercussão inclusive porque realizadas em sede da própria ONU, em Genebra (o que lhes dava um aspecto de reunião rotineira, incapaz de atrair as atenções dos media). Na verdade, porém, o racismo e a discriminação racial, juridicamente proscritos, nunca haviam sido seriamente abordados em sua incidência planetária. Qualquer reunião internacional sobre a matéria era deturpada pela existência do apartheid sul-africano, objeto de fixação de atenções pelo mal que trazia em si e como ameaça à paz e à segurança, agravada pelo contexto de confrontação bipolar. A isso se somava desde então a sempre explosiva questão do Oriente Médio, trazida às discussões 
do tema com uma "legitimidade" irrefutável porque decorrente da equiparação do sionismo ao racismo em inúmeros documentos vigentes. ${ }^{7}$

Em 1994, o fim do regime aparteísta, coroado com a posse de Nelson Mandela como Presidente da República da África do Sul, escolhido em eleições livres de que pela primeira vez participara todo o povo do país, abria o caminho para uma visão mais nítida do racismo como o fenômeno generalizado que é. E a equiparação internacional do sionismo ao racismo fora, por sua vez, abolida por resolução da Assembléia Geral das Nações Unidas desde 1992.

Enquanto esses fatos pareciam demonstrar a viabilidade de uma conferência mundial imbuída de novo espírito, outros elementos, velhos e recentes, fortaleciam a necessidade de sua realização. Após a eliminação, com auxílio das sanções da ONU, do sistema constitucional aberrante que erigira a segregação em essência do Estado mais poderoso da África subsaárica, numa época em que a igualdade formal entre as raças já fora estabelecida por lei em quase todos os países, era preciso que o mundo "globalizado" atentasse para as manifestações estruturais do racismo contemporâneo. Vigorosamente denunciado no Brasil pelo movimento negro e por membros da Academia, tão disseminado no "Ocidente" que autores norte-americanos hoje falam da "brasilianização da América”, ${ }^{8}$ o racismo insidioso, consciente ou inconsciente, que mantém grandes contingentes populacionais em situação de inferioridade social é, quiçá, mais difícil de combater do que as manifestações ostensivas de inferiorização racial, na medida em que se dissimulam debaixo de direitos civis distorcidos.

A esses fatos capazes de fundamentar de per si uma nova conferência, a ser sediada na África do Sul pós-apartheid pelo valor simbólico da localização (assim se pensou desde o primeiro momento), acresciam novos surtos violentos de discriminação, xenofobia e outras formas contemporâneas correlatas de intolerância ${ }^{9}$ que se vinham multiplicando mundo afora. Elas se consubstanciavam inter alia em agressões a imigrantes na Europa; no ressurgimento de doutrinas "supremacistas” brancas nos Estados Unidos, inspiradoras de "milícias” armadas; nas matanças intertribais da África, paroxísticas no caso de Ruanda; no recrudescimento de conflitos etno-religiosos asiáticos, com mortes e profanações de templos; na violência e vandalismo de skinheads e grupos neonazistas dos dois lados do Atlântico (até mesmo no Brasil, que é capaz de copiar todos os piores modismos do chamado Primeiro Mundo); ${ }^{10}$ no agravamento do micronacionalismo fascistóide traduzido em "limpezas étnicas" e guerras civis cruentas. Ainda mais ominoso, tudo isso era acompanhado pelo fortalecimento eleitoral, nas democracias modelares, de partidos populistas de extrema direita, para os quais o "orgulho nacional" do "homem médio do povo", associado ao racismo, à xenofobia e ao anti-semitismo eram elementos demagógicos de plataformas programáticas.

Vivíamos, pois, num período em que, de um lado, o multilateralismo era visto positivamente como instrumento de melhora da situação planetária (e o próprio 
fim do apartheid era evidência de que o trabalho multilateral, no longo prazo, dava frutos). Mas vivíamos também, de outro, numa realidade em que, contrariando as imagens do "fim da História" e da democracia como novo "horizonte intransponível" da política, a bipolaridade estratégica havia cedido lugar a uma infinidade de tensões e embates bélicos, provocados por discriminações quase todas enquadradas na definição do Artigo $1^{\circ}$ da Convenção Internacional sobre a Eliminação de Todas as Formas de Discriminação Racial, de 1965:

“...qualquer distinção, exclusão, restrição ou preferência baseadas em raça, cor, descendência ou origem nacional ou étnica que tem por objetivo ou efeito anular ou prejudicar o reconhecimento, gozo ou exercício, em igualdade de condições, dos direitos humanos e liberdades fundamentais nos domínios político, econômico, social, cultural ou qualquer outro da vida pública”.

A percepção da necessidade de uma conferência para tratar desses problemas era nítida aos olhos de todos os membros da Subcomissão, que exercem seus mandatos nesse órgão da ONU a título pessoal, atuando, em princípio, segundo as próprias convicções. Dela emergiu, portanto, a Resolução 1994/2, denominada "Uma conferência mundial contra o racismo, a discriminação racial ou étnica, a xenofobia e outras formas contemporâneas correlatas de intolerância” (é importante notar que o título da resolução - assim como da conferência proposta - referia-se expressamente às formas contemporâneas das manifestações desse fenômeno), a se realizar em 1997, na seqüência de grandes encontros já realizados ou programados desde o fim da Guerra Fria. ${ }^{11}$

A necessidade e as possibilidades promissoras de um evento sobre o racismo e a xenofobia contemporâneos também pareceram claras à Comissão dos Direitos Humanos das Nações Unidas, de caráter governamental, que endossou a proposta dessa Conferência na primeira sessão subseqüente à da Subcomissão, em 1995, assim como, no mesmo ano, ao Conselho Econômico e Social (ECOSOC), que aprovou e encaminhou a proposta à Assembléia Geral. Neste último foro, verdadeira instância decisória para empreendimentos dessa magnitude, a reação foi diferente. Países ocidentais manifestaram, já em 1995, dúvidas sobre a oportunidade da idéia. Afinal, uma conferência sobre esse tema, por mais global que se comprovasse, iria tratar de assuntos para eles particularmente incômodos. Sem mencionar que, nas circunstâncias da globalização atual, a exclusão social é efeito colateral esperado, a iniqüidade racial era uma seara em que, ao contrário das demais (meio ambiente, direitos humanos, crescimento populacional e situação da mulher), não lhes seria viável situar alhures o locus preferencial dos problemas. ${ }^{12}$ Nem atribuir a outrem suas causas mais profundas.

A Assembléia Geral somente aprovou a idéia da Conferência na sessão regular de 1997, dentro da Resolução 52/111, sobre a "Terceira Década de Combate ao Racismo e à Discriminação Racial”. Pelo artigo 28 dessa longa resolução 
programática finalmente decidiu-se convocar uma "conferência mundial sobre o racismo e a discriminação racial, a xenofobia e intolerância correlata" (note-se que a menção às outras formas contemporâneas correlatas de intolerância havia sido substituída pela expressão inovadora “intolerância correlata”, de sentido impreciso, diferente do que eu imaginara). ${ }^{13}$ Entre seus objetivos, além daqueles mais habituais (examinar os progressos alcançados e obstáculos enfrentados para a superação dos problemas; aumentar o nível de conscientização para eles; formular recomendações; etc.), incluía-se o de rever (to review) os "fatores políticos, históricos, econômicos, sociais, culturais e de outra ordem conducentes ao racismo, à discriminação racial, à xenofobia e à intolerância correlata”, seguindo-se o de "formular recomendações concretas de medidas eficazes (action-oriented) nacionais, regionais e internacionais” para combater os problemas. Estavam aí as sementes de algumas das divergências mais difíceis. Ao modificar no título a fórmula original “... e outras formas contemporâneas correlatas de intolerância” para "intolerância correlata” a Assembléia expandia, talvez até com razão, o escopo da conferência para áreas indefinidas (algumas das quais, por mais pertinentes que fossem, não teriam sido aceitas sequer na Subcomissão). Ao incluir nos objetivos a revisão dos fatores históricos do racismo, a Resolução 52/111 abria o caminho para acusações que poderiam, em princípio, remontar até a Antigüidade distante e para cobranças atuais - as famosas "reparações" - entendidas de maneiras divergentes entre seus próprios defensores. Além disso, a resolução decidia, no artigo 29, que a conferência seria convocada "não depois do ano de 2001".

Contemplada pela Subcomissão como um evento dedicado aos problemas do presente, herdados ou não do passado, voltado para o futuro, a Conferência era encarada, na origem, como chave de ouro oportuna para a série final de encontros do Século XX. Tal como aprovada pela Assembléia Geral, abrangendo todas as discriminações existentes, com cobranças (até em dinheiro) pelos males do passado, ela se tornava ambiciosa demais.

Complexa, mas não-irrealista nas circunstâncias de 1994, a Conferência contra o Racismo se afigurava onírica, mais do que ingênua, na situação sombria, justificadamente pessimista (ainda antes do Onze de Setembro), do início no Século XXI.

\section{As principais dificuldades}

Para quem observa superficialmente os desentendimentos havidos na Conferência de Durban pode parecer, à primeira vista, que os problemas tenham decorrido, de um lado, da insistência dos países árabes na reequiparação - nãoexplícita, mas evidentemente implícita - do sionismo ao racismo, já rejeitada pela ONU desde 1992, com a conseqüente defecção dos Estados Unidos e de Israel. De outro lado, as dificuldades estariam na rejeição ocidental à idéia de reparações 
pela prática da escravidão. Tais visões são verdadeiras, mas não suficientemente abrangentes.

Apegados ao longo período em que a luta anticolonialista do Movimento Não-Alinhado encampava com grande vigor a causa palestina e se refletia facilmente em documentos da ONU com a reiteração de que o sionismo era uma forma de racismo, os árabes foram realmente demasiado virulentos contra os judeus nas propostas de parágrafos que abordavam o conflito do Oriente Médio (não se podendo, porém, negligenciar o fato de que o novo Governo conservador israelense tomava iniciativas consideradas provocatórias, como o reinício do estabelecimento de “colônias" em território palestino). A linguagem por eles postulada para alguns parágrafos dos anteprojetos referiam-se, por exemplo, aos sofrimentos causados aos palestinos como um novo holocausto. Caso aceita, tal formulação soaria mais radical do que a qualificação do sionismo como uma forma de racismo, pois equipararia o Estado de Israel à Alemanha de Hitler. Ao se apropriar de um dos mais dolorosos momentos da História do Século XX, a fórmula do "novo holocausto", ou, como aparecia em certas propostas, a referência a "Holocaustos" no plural, banalizaria o extermínio metódico dos judeus nos campos nazistas como um fenômeno não-excepcional. Contudo, a rejeição peremptória a tais formulações já havia sido externada por grande número de delegações (inclusive a do Brasil) no Comitê Preparatório, tendo ficado demonstrado que elas não seriam aceitas nos documentos da Conferência.

Quanto ao abandono das negociações por Estados Unidos e Israel em Durban, ela não chegou a constituir novidade. A retirada de Washington, sob a Administração de George W. Bush, de tratados, encontros e concertações internacionais já se tornara corriqueira. Exemplos haviam sido registrados com relação ao Protocolo de Kyoto, ao Tribunal Penal Internacional, à conferência internacional para o controle de armas leves e aos esforços para o estabelecimento de um regime de inspeções eficaz para a Convenção sobre Armas Biológicas (sem falar nos acordos ABM com Moscou). Nem por isso esses esforços e construções jurídicas ou quase jurídicas multilaterais passaram a ser desprezadas. No que diz respeito a reuniões mundiais específicas contra o racismo, pior já ocorrera em 1978, quando, por motivos assemelhados, as delegações ocidentais se ausentaram em bloco, esvaziando as negociações da primeira conferência. E na segunda conferência, em 1983, os Estados Unidos, Israel e a África do Sul também se retiraram, sendo a Declaração final adotada por votação, de 101 contra $12^{14}$ (o que significa que para esses 12 opositores, a Declaração de 1983 nunca foi reconhecida).

A diferença fundamental em Durban, para a qual não atentaram os Governos de Washington e Tel-Aviv, estava no fato de que, em 2001, ao contrário do que se verificara quando da primeira e da segunda conferência contra o racismo, a aliança aguerrida do Movimento Não-Alinhado se desvanecera. Não mais 
contando com apoio do extinto bloco socialista, desde 1992 os próprios NãoAlinhados haviam sido forçados a abjurar - ou aceitar a revogação pela maioria dos votantes - das resoluções e outros textos que estabeleciam ser o sionismo uma forma de racismo. Para o êxito da Conferência, as mais altas autoridades das Nações Unidas, do Secretário Geral, Kofi Annan à Alta Comissária para os Direitos Humanos, Mary Robinson, cientes da obstinação dos árabes, recordavam de público, com insistência, achar-se essa questão definitivamente ultrapassada, não fazendo sentido reabri-la. Não seria, portanto, muito difícil, se para isso houvesse vontade, superar, em negociações construtivas, a veemência daqueles que, instigados ou não pelas novas atitudes de Israel, persistiam em querer transformar uma grave questão político-nacionalista de fundo religioso num problema de direitos humanos. ${ }^{15}$

A questão das reparações pela escravidão, a que se associava a idéia de um pedido de perdão pelo colonialismo, foi, sem dúvida, das mais complexas, inclusive por não se tratar de reivindicação unívoca. Dentro dos movimentos negros do continente americano como um todo, as propostas já variavam desde a de adoção de políticas públicas eficazes, na linha das quotas ou preferências estabelecidas nos Estados Unidos na seqüência do movimento pelos direitos civis dos anos 50-60, a postulações de indenizações em dinheiro, a serem pagas, em bloco ou individualmente, aos descendentes vivos dos escravos (essa idéia nunca chegou a ser claramente explicitada, não se tendo sabido nunca quem pagaria o quê, como e a quem). Envolvia, em sentido inteiramente distinto, a reivindicação de compensações interestatais, cobrada pelo Grupo de Estados Africanos, na forma de doações financeiras, de esquecimento da dívida ou de assistência aumentada. Tal postulação, de sentido Sul-Norte, pela insistência com que se apresentava, demonstrava não apenas uma diferença de enfoque entre os africanos da África e seus parentes da diáspora, como também uma diferença essencial na maneira de interpretar a natureza da Conferência: para o Grupo Africano ela deixava de ser um encontro sobre direitos humanos para constituir um foro eminentemente econômico.

A todas essas cobranças o Grupo Ocidental se opunha, como era, obviamente, esperado. O que não era esperado foi o nível de rigidez e obstrução por ele manifestado nos parágrafos mais simples. Ao contrário do ocorrido em 1993, na Conferência de Viena, quando, em geral, ajudavam a formular linguagem conducente ao consenso, em Durban, países ocidentais freqüentemente assumiam posições "bizantinas”, com propostas de alterações ridículas para os textos mais anódinos, como se quisessem deixar clara sua antipatia pela Conferência. Para as questões difíceis, uma de suas táticas consistia em espalhar boatos de uma possível retirada coletiva, deixando para "o dia seguinte” a decisão sobre a matéria. Mas essa tática, como ficou desde cedo comprovado, longe de obter concessões, sempre tendia, ao contrário, a aumentar a vociferação dos demais. Nessas condições, tanto quanto as posturas árabes, excessivas, mas monotemáticas, ou a insistência 
africana em reparações pela escravidão e pedido de perdão formal pelo colonialismo, a inflexibilidade e a provocação constante de Estados do Ocidente produzia a impressão desalentadora de que todo o trabalho de Durban seria uma experiência vã. ${ }^{16}$

Para se ter uma idéia minimamente aproximada da massa de dificuldades envolvidas na Conferência, convém que se tome em consideração todos os "temas" por ela tratados, pois todos eles continham fontes de controvérsias, às vezes surpreendentes (os "temas" foram aprovados, com colchetes indicativos de falta de consenso em torno da palavra "compensatórias" desde a primeira sessão do Comitê Preparatório, em Genebra, em maio de 2000, até o final da terceira e extraordinária sessão, de 30 de julho a 10 de agosto, também em Genebra, vinte dias antes do início da própria Conferência, ${ }^{17}$ assim encaminhados a Durban e finalmente lá endossados). Os “temas” eram:

- Fontes, causas, formas e manifestações contemporâneas de racismo, discriminação racial, xenofobia e intolerância correlata;

- Vítimas de racismo, discriminação racial, xenofobia e intolerância correlata;

- Medidas de prevenção, educação e proteção voltadas para a erradicação do racismo, da discriminação racial, da xenofobia e da intolerância correlata nos níveis nacional, regional e internacional;

- Provisão de remédios efetivos, recursos, correção, assim como medidas [compensatórias] e de outra ordem nos níveis nacional, regional e internacional;

- Estratégias para alcançar a igualdade plena e efetiva, inclusive por meio da cooperação internacional e do fortalecimento das Nações Unidas e outros mecanismos internacionais para o combate ao racismo, à discriminação racial, à xenofobia e à intolerância correlata, assim como o acompanhamento de sua implementação. ${ }^{18}$

Até mesmo os dois primeiros "temas", aparentemente inocentes, concernentes à definição das fontes e causas do racismo, assim como a relação de suas vítimas, foram submetidos a tantas e tamanhas controvérsias que, para se tentar saná-las, foram agrupados num dos três grandes conjuntos de "questões difíceis”, ainda nas discussões do Comitê Preparatório, sendo atribuída ao México a função de "facilitador" para buscar o consenso. Os problemas que se apresentavam eram vários. A Índia não aceitava que se incluíssem os párias ou dalits entre as vítimas (enquanto do lado de fora das salas de reunião párias procedentes do subcontinente indiano e simpatizantes vários de outras nacionalidades faziam manifestações e vigílias para que a situação dos “intocáveis” não fosse deixada de lado), com a alegação de que as castas não decorrem de raça. As 
mulheres, estimuladas por suas conquistas nas Conferências do Cairo, em 1994, e de Pequim, em 1995, insistiam, pela voz de muitas delegações, na inclusão do gênero como fonte de discriminações agravadas. Utilizando-se da expressão "intolerância correlata”, os países ocidentais lato sensu, nesse caso liderados pelo Brasil, traziam ao proscênio o problema da discriminação por orientação sexual, sofrida pelos homossexuais, universal, mas ainda tabu em diversos meios e sociedades, não-reconhecida sequer como discriminação porque legalmente criminalizada em muitos países, por preconceito ou motivação religiosa.

Somente na véspera da data prevista de encerramento da Conferência, a exausta delegação mexicana logrou anunciar o acordo - absurdamente tautológico - a que se conseguira chegar sobre o tema das “vítimas", assim como a formulação - minimalista, reproduzindo ipsis litteris o Artigo $1^{\circ}$ da Convenção sobre a Eliminação de Todas as Formas de Discriminação Racial, 1965 - das "causas (ou fontes)" de discriminações primárias, acrescentando-se como fontes adicionais para as discriminações múltiplas ou agravadadas a expressão acomodatícia "por outros motivos correlatos", seguida de termos incontroversos, extraídos da Declaração Universal dos Direitos Humanos, a título exemplificativo. Tal acordo se lê nos artigos 1 e 2 da Declaração de Durban, ${ }^{19}$ que rezam:

“1. Declaramos que, para efeitos da presente Declaração e Programa de Ação, as vítimas do racismo, discriminação racial, xenofobia e formas correlatas de intolerância são os indivíduos ou grupos de indivíduos que sejam ou tenham sido afetados negativamente por esses flagelos, submetidos a eles ou seu alvo.

2. Reconhecemos que o racismo, a discriminação racial, a xenofobia e as formas correlatas de intolerância são produzidas por motivos de raça, cor, descendência, origem nacional ou étnica, e que as vítimas podem sofrer formas múltiplas ou agravadas de discriminação por outros motivos correlatos, como o sexo, o idioma, a religião, opiniões políticas ou de outra índole, origem social, situação econômica, nascimento ou outra condição."20

Sem pretender esgotar, nem de longe, a descrição das controvérsias e circunstâncias que quase levaram à inexistência de documentos finais em Durban, pode-se assinalar, por exemplo, sobre os temas das "medidas de prevenção, educação e proteção para erradicar o racismo" e das "estratégias para se alcançar a igualdade plena", que a expressão corrente ação afirmativa foi banida da Conferência, por mais que os movimentos negros - inclusive o brasileiro - e outros grupos organizados presentes ao evento a defendessem. E foi banida exatamente pelo país que a inventou, na linguagem e na prática: os Estados Unidos. Isso porque, como é sabido, ainda nos tempos do democrata liberal Bill Clinton, alguns Estados norte-americanos, começando pela Califórnia, já a haviam legalmente abolido. No Governo republicano, tal tendência deveria logicamente intensificar-se. Daí a 
objeção dos delegados norte-americanos sempre que ela aparecia. E de nada adiantou, para a linguagem dos documentos, a retirada dos Estados Unidos. Seus aliados mais fiéis presentes velaram zelosamente para que essa expressão, hoje universalmente consagrada, não reaparecesse em qualquer parágrafo.

Outro fato que merece ser lembrado, pela ironia de que se reveste, foi a quantidade de vezes que, em meio a negociações emperradas sobre os assuntos mais delicados, certas delegações européias fizeram questão de afirmar sua nãoaceitação da noção de raça. Como se Ernest Renan, Le Bon, Lapouge, Gumplowicz, Franz Gall, John Hunt e nosso velho conhecido Gobineau, sem falar de Spencer e Galton, ou, mais tenebrosamente, do nacional-socialismo alemão, não tivessem sido europeus, inspiradores de políticas conseqüentes! ${ }^{21}$ Por mais meritória que fosse a recusa dessa noção, ela, em geral, funcionava como mero complicador adicional de discussões já acirradas. Além disso, é preciso ter em mente que, se elevada a extremos, essa rejeição fora de contexto poderia $a d$ absurdum esvaziar a rationale da Conferência, da Convenção sobre a Eliminação de Todas as Formas de Discriminação Racial e dos demais instrumentos de combate ao racismo. Por uma questão de lógica, a inexistência de raças poderia representar inexistência de racismo, justificando uma inação, que ninguém ousaria, na Conferência, suscitar como posição.

Todos de boa fé sabem que "raça” é, sobretudo, uma construção social, negativa ou positiva conforme o objetivo que se lhe queira dar. Pode ou não envolver traços físicos, cor de pele, língua, religião ou costumes “racializados”. Com sentido romanticamente comunitário, a idéia de "raça” fundamentou a formação dos Estados nacionais europeus (particularmente a Alemanha unificada no Século XIX, mas a Data Nacional de Portugal, que celebra Camões e sua poesia, chama-se também "Dia da Raça"), assim como serviu de base à expansão colonialista, justificando a dominação "civilizadora” de populações “inferiores”. Nesse mesmo sentido identitário, agora com os sinais trocados, a raça tem sido atualmente usada pela esquerda como amálgama de auto-afirmação para quem antes era, ou ainda permanece, depreciado pelos demais. E ao mesmo tempo serve ao diferencialismo racista da direita, que rejeita os imigrantes, os estrangeiros, os diferentes, porque “culturalmente inassimiláveis”.

O problema não está na existência ou não de raças, mas no sentido que se dá ao termo. Se atribuirmos caracteres inerentes, naturais e inescapáveis, às diferenças físicas, psíquicas, lingüísticas ou etno-religiosas de qualquer população, estaremos sendo racistas, quase sempre para o mal. Como explicita Wierwiorka, o racismo hoje em voga é muito mais cultural e diferencialista do que científico e instrumental, como ocorreu no passado. Seja com base "científica”, universalista mas inferiorizante, ou "cultural" diferencialista e excludente, a verdade nua e crua é que o racismo existe, segrega, discrimina e mata. Fenômeno socio-econômico e político, ele faz estragos terríveis em primeiro lugar às vítimas e sua coletividade. 
Fá-lo também à sociedade como um todo, onde os inocentes, acomodados ou não, são igualmente alvo do ódio retribuído.

Posturas ridículas no contexto das negociações à parte, é bom que a Conferência tenha afirmado, no artigo 7 da Declaração:

“7. (...) Toda doutrina de superioridade racial é cientificamente falsa, moralmente condenável, socialmente injusta e perigosa, devendo ser rechaçada juntamente com as teorias que procuram determinar a existência de raças humanas separadas”.

Também parece positivo o fato de que a União Européia, em adição a esse artigo, tenha feito questão de assinalar, no encerramento do encontro, pela voz da delegação da Bélgica, então presidente dos “quinze”, que todos os seus Estados membros

“... rechaçam firmemente qualquer doutrina que proclame a superioridade racial, juntamente com as teorias que tentam determinar a existência de raças humanas distintas (...). Isto não implica negação do conceito de raça como motivo de discriminação, nem negação das manifestações de racismo e discriminação racial, segundo definidas pelo Artigo $1^{\circ}$ da Convenção (de 1965), que ainda existem em todo mundo".

À luz das atitudes coletivas de repúdio, adotadas pouco antes pela União Européia, diante da chegada ao poder de partido semi-nazista em um de seus Estados membros, e do crescimento da popularidade de "frentes", "ligas” ou partidos ultranacionalistas - micronacionalistas em alguns casos - com programas baseados na fustigação de imigrantes provenientes de regiões mais pobres, tal declaração dos quinze, logo seguida pela Suíça, mais do que uma explicação genérica, soava como uma autocrítica ou, quiçá, auto-advertência. Pois neste início de século, em tendência confirmada eleitoralmente na Europa ao longo de 2002, assim como desde antes em países da Ásia, a atribuição de culpa aos estrangeiros pelas mazelas vividas tornou-se verdadeira constante.

\section{A busca de soluções}

Sublinhando mais uma vez que as divergências acima mencionadas foram importantes, mas nem de longe as únicas, cabe agora dar uma idéia dos processos pelos quais se "solucionaram" as principais dificuldades, a saber: o grupo de parágrafos relacionados com o conflito árabe-israelense e o dos atinentes às chamadas "questões históricas”, em que se incluía a idéia de reparações atuais. Para ambos, a exemplo do que se passava com o já descrito problema das "fontes e vítimas” com coordenação do México, haviam sido designados na última sessão do Comitê Preparatório dois “coordenadores”: a África do Sul (na qualidade de 
país anfitrião) para o Oriente Médio e o Brasil para os “temas do passado”. Nada foi possível adiantar, até porque os Estados diretamente interessados não queriam reunir-se. Em Durban, a Presidenta da Conferência, Nkosazana Dlamini Zuma, Ministra das Relações Exteriores da África do Sul, decidiu reconstituir os três grupos informais de trabalho, mantendo como coordenadores o México para o primeiro conjunto; o Brasil (na figura do Embaixador Gilberto Sabóia, Chefe alterno da delegação brasileira), ${ }^{22}$ como coordenador das “questões históricas”, assistido pelo Quênia; a Noruega, em função dos “acordos de Oslo”, para os parágrafos relativos ao Oriente Médio, auxiliada pela Namíbia.

Na medida em que, em contraste com os dois primeiros grupos, aquele correspondente ao Oriente Médio não mostrava nenhuma evolução positiva com o passar dos dias, a Chanceler sul-africana arrogou a si mesma essa tarefa de coordenação aparentemente impossível, estabelecendo como auxiliares cinco representantes dos diferentes grupos regionais. Tanto o México, como o Brasil e a Chanceler sul-africana, após ouvirem as diferentes - e múltiplas - posições conflitantes sobre os diferentes parágrafos, tomaram o mesmo tipo de iniciativa: a partir das intervenções ouvidas - muitas vezes até o amanhecer -, escreveram novos conjuntos de parágrafos para os assuntos respectivos, os quais deveriam substituir, na Declaração e Programa de Ação de Durban, tudo o que se referisse às questões em pauta, apagando-se, pois, aquilo que constava, sem acordo, dos anteprojetos recebidos do Comitê Preparatório. ${ }^{23}$

Com exceção dos assuntos coordenados pelo México, cuja redação final minimalista foi apresentada ao Comitê de Redação pouco antes da data marcada para o encerramento da Conferência, os novos parágrafos sobre o Oriente Médio e sobre os assuntos históricos foram apresentados pelos respectivos coordenadores, já no dia 8, diretamente ao Comitê Plenário, que os acolheu. Mas aí se iniciou um novo processo que quase põe tudo a perder.

Insatisfeitos com o tom mais moderado dos parágrafos sobre o Oriente Médio, os países integrantes da Organização da Conferência Islâmica, pela voz da delegação da Síria, retomaram alguns dos parágrafos mais controvertidos dos anteprojetos, superados pelos novos textos recém-aprovados, supostamente consensuais, e os reapresentaram à consideração do Comitê. Diante da surpresa generalizada, muita movimentação na mesa, consultas formuladas ao Consultor Jurídico da ONU, e após uma nova suspensão dos trabalhos de duas horas (quando a Conferência deveria ter terminado na véspera!), o Brasil, em ação corajosa, visando a salvar a Conferência, formulou, com base no regulamento vigente, moção de não-consideração desses textos reapresentados. Nova confusão se armou, na medida em que delegados atordoados não notaram ou não entenderam que, também de acordo com o regulamento, a moção brasileira, para ser válida, precisaria ser secundada de público por pelo menos dois outros países, enquanto a Síria e a Argélia a ela logo se opuseram. Isolado (pela incompetência alheia), o Brasil viu- 
se forçado a retirar a proposta. Quando finalmente entendida a oportunidade desperdiçada, a Bélgica, em nome dos quinze membros da União Européia, retomou a iniciativa brasileira, reapresentando ao Comitê Principal a moção de nãoconsideração. A moção foi, então, submetida à votação, sendo aprovada por 51 a favor, 37 contra e 11 abstenções. Passou, assim, por voto a moção de nãoconsideração desses parágrafos controvertidos (portanto, definitivamente anulados), mas não foi objeto de escrutínio o conjunto alternativo. Isso permitiu ao Comitê Principal e, posteriormente, ao Plenário, adotar sem voto a Declaração e o Programa de Ação, tornando os resultados de Durban ipso facto mais positivos do que os das duas conferências anteriores sobre o racismo. ${ }^{24}$

Embora não caiba aqui repetir integralmente os textos afinal aprovados para essas questões candentes, vale a pena recordar, porque auto-explicativos à luz do que já foi antes assinalado, alguns desses novos parágrafos adotados sem voto (todos os quais foram inseridos, após outros contratempos entre o fim da Conferência e a Assembléia Geral, na Declaração de Durban):

a) a propósito do conflito árabe-israelense

“58. Recordamos que o Holocausto não deve ser nunca esquecido.

61. Reconhecemos com profunda preocupação o aumento do anti-semitismo e da islamofobia em diversas partes do mundo, assim como o aparecimento de movimentos raciais e violentos baseados no racismo e em idéias discriminatórias contra as comunidades judia, muçulmana e árabe.

63. Preocupam-nos os padecimentos do povo palestino submetido à ocupação estrangeira. Reconhecemos o direito inalienável do povo palestino à autodeterminação e ao estabelecimento de um Estado independente e reconhecemos o direito à segurança de todos os Estados da região, inclusive Israel. Fazemos um chamamento a todos os Estados para que apóiem o processo de paz e o levem a uma pronta conclusão.

64. Apelamos por uma paz justa, abrangente e duradoura na região, em que todos os povos coexistam e desfrutem de igualdade, justiça e os direitos humanos internacionalmente reconhecidos, assim como de segurança.

65. Reconhecemos o direito dos refugiados de regressarem voluntariamente a seus lares e propriedades em condições de dignidade e segurança, e instamos a todos os Estados que facilitem esse retorno.”

b) sobre as "questões históricas"

"13. Reconhecemos que a escravidão e o tráfico de escravos, em particular o tráfico transatlântico, foram tragédias atrozes na história da humanidade, não 
apenas por sua abominável barbárie, mas também por sua magnitude, seu caráter organizado e, especialmente, sua negação da essência das vítimas. Reconhecemos ainda que a escravidão e o tráfico de escravos, especialmente o tráfico transatlântico, são, e sempre deveriam ter sido, um crime contra a humanidade e se encontram entre as maiores fontes e manifestações de racismo, discriminação racial, xenofobia e intolerância correlata, e que os africanos e afrodescendentes, os asiáticos e descendentes de asiáticos, assim como os povos indígenas, foram vítimas de tais práticas e continuam a sê-lo de suas conseqüências.

14. Reconhecemos que o colonialismo levou ao racismo, à discriminação racial, à xenofobia e a formas correlatas de intolerância, e que os africanos e afrodescendentes, os asiáticos e descendentes de asiáticos, assim como os povos indígenas, foram vítimas do colonialismo e continuam a sê-lo de suas conseqüências. Reconhecemos os sofrimentos causados pelo colonialismo e afirmamos que, onde e quando quer que ele tenha ocorrido, deve ser condenado e impedido de ocorrer novamente. Ademais lamentamos que os efeitos e a persistência dessas estruturas e práticas sejam dos fatores que contribuem para as desigualdades sociais e econômicas duradouras em muitas partes do mundo de hoje.

100. Reconhecemos e lamentamos profundamente os sofrimentos e males indizíveis infligidos a milhões de homens, mulheres e crianças como resultado da escravidão, do tráfico de escravos, do tráfico transatlântico de escravos, do apartheid e de tragédias passadas. Notamos também que alguns Estados têm tomado a iniciativa de pedir perdão e de pagar indenização, conforme apropriado, para as graves e maciças violações cometidas.

101. Com vistas a dar por encerrados esses capítulos sombrios da história e como uma um meio de reconciliação e cicatrização de feridas, convidamos a comunidade internacional e seus membros a honrar a memória das vítimas dessas tragédias. Ademais notamos que alguns têm tomado a iniciativa de lamentar ou de expressar remorso ou de pedir perdão, e instamos a todos que ainda não tenham contribuído para restaurar a dignidade das vítimas que procurem meios apropriados de o fazer. Nesse sentido, expressamos nossa apreciação pelos países que já o fizeram.”

Embora os artigos acima reproduzidos de maneira não seqüencial já formem lista comprida, o total de textos redigidos pelos coordenadores e inseridos na Declaração de Durban em substituição àqueles dos anteprojetos para os quais não havia possibilidade de consenso é mais longo. Tais como finalmente adotados, os novos textos não agradaram inteiramente a nenhuma das posições maximalistas. Mas isso é diplomacia, na melhor acepção do termo: a busca de um mínimo denominador comum que não permitirá a ninguém apresentar-se como vencedor absoluto, nem ser apontado como totalmente derrotado. Assim sendo, como é normal em qualquer evento do gênero, diversas delegações, na sessão de encerramento, fizeram questão de assinalar reservas ou explicações interpretativas. 
Com relação aos parágrafos sobre o Oriente Médio, alguns ocidentais registraram reservas ao texto que constitui atualmente o parágrafo 65, suprareproduzido, pois consideravam que o direito de regresso dos refugiados por ele consignado constituiria um complicador adicional aos (hoje totalmente esquecidos) “acordos de Oslo", justificando, em última instância, rejeição à existência do Estado de Israel. Mas é fato também que, no contexto, ele pode ser lido como o simples direito de regresso a suas casas dos palestinos expelidos em função de "assentamentos" israelenses em territórios ocupados por guerras (é importante recordar que a autorização para o reinício do estabelecimento de tais "colônias" foi das primeiras atitudes adotadas pelo Governo de Ariel Sharon). Os árabes, por sua vez, juntamente com outras delegações de países muçulmanos, declararam, em linhas gerais, que os parágrafos adotados sobre o Oriente Médio não refletiam corretamente a gravidade da situação (e o futuro próximo iria comprovar que não estavam errados, no que concerne tanto aos palestinos como à população israelense). A propósito das "questões históricas", resolvidas de maneira notavelmente construtiva, verifica-se, por exemplo, que as "reparações" ou "pedidos de perdão" pela escravidão e o colonialismo não são exigidos, porque não o poderiam ser. Mas elogiam-se os países que tenham tomado essas iniciativas e faz-se chamamento àqueles que não o fizeram para que encontrem maneiras adequadas de "restabelecer a dignidade das vítimas”. Tampouco foi aceita a qualificação da escravidão passada como um "crime contra a humanidade", como era desejo dos africanos, porque ela poderia, segundo consta, servir de base a cobranças judiciais. De qualquer forma, historicamente a escravidão era prática corrente e tristemente legal, não existindo no Direito essa tipologia de crime (só estabelecida, após a II Guerra Mundial, pelos Tribunais de Nuremberg e de Tóquio). Daí a fórmula do parágrafo 13 declarar a escravidão e o tráfico de escravos como um crime contra a humanidade (subentende-se que o são quando praticados atualmente), acrescentando que sempre o deveriam ter sido. Muitas delegações africanas e caribenhas expressaram em declarações finais apoio aos textos acordados, mas sublinharam mais uma vez suas opiniões originais. E a respeito da questão das fontes e vítimas, definidas de forma tautológica e minimalista, até mesmo o Brasil, em sua declaração final, considerou os resultados aquém do desejado, por não explicitarem o gênero, as deficiências e a orientação sexual entre os motivos de discriminação múltipla ou agravada. ${ }^{25}$

\section{Os pontos mais positivos}

Para os negociadores em Durban, exaustos e confundidos, os pontos mais positivos pareceriam ser exatamente aqueles mais polêmicos, para os quais afinal se conseguira acordo, ainda que extraído a fórceps. Pelo menos porque esse difícil acordo lhes parecia haver "salvado" a Conferência do mesmo destino de ostracismo 
que tiveram os dois encontros precedentes sobre o racismo, nas décadas de 70 e 80. E até certo ponto teriam razão.

Se é inadequado falar de "acordo" para os parágrafos sobre o conflito árabe-israelense, que, conforme já visto, somente prevaleceram por manobra procedimental, o mesmo não se pode dizer dos chamados "temas do passado". Sem dúvida menos incisivos e menos propícios à abertura de processos indenizatórios do que desejavam países e movimentos sociais, eles são, ainda assim, o que de mais avançado existe na esfera internacional como condenação semi-jurídica ao colonialismo, à escravidão e ao tráfico de escravos, incriminados, inclusive, como origem de muitos dos sofrimentos presentes, de índios e afrodescendentes.

Os índios - aliás, os poucos povos indígenas que encaram o direito de autodeterminação como caminho para a independência - podem ter-se sentido frustrados pelas ressalvas feitas na Declaração de que o reconhecimento dos direitos dos povos indígenas era feito conforme os princípios de soberania e integridade territorial dos Estados, sem repercussões sobre negociações em curso e sobre direitos reconhecidos em normas jurídicas internacionais (artigos 23 e 24). Mas a expressão "povos indígenas" viu-se sacramentada como tal, tendo-se tornado inclusive um dos subtítulos na parte do Programa de Ação concernente às vítimas do racismo e da discriminação racial. Nele, diversas medidas são propostas aos Estados para o reconhecimento dos direitos dos indígenas, a começar pelo respeito a sua cultura e sua participação em todas as decisões que os envolvam (parágrafos 15 a 23 do Programa - o recorte de gênero é, aliás, assinalado nesses parágrafos como causa freqüente de atos de discriminação múltipla ou agravada: contra as mulheres e meninas índias).

Se os avanços obtidos para os povos indígenas soam relativamente pouco inovadores, na medida em que eles têm sido objeto de atenções das Nações Unidas há muitos anos, o reconhecimento das dificuldades que enfrentam os africanos e seus descendentes na diáspora, assim como a grande quantidade de artigos e recomendações para corrigir as disparidades de que são vítimas nas sociedades atuais constituem uma importante novidade. A eles se dedica o primeiro subtítulo do capítulo das vítimas no Programa de Ação, com inúmeras recomendações aos Estados (parágrafos 4 a 14 do Programa), as quais, ademais de visarem a sua proteção judicial, ao reconhecimento de sua cultura e à supressão das discriminações contra suas tradições e religiões, propõem uma série de iniciativas nas áreas de educação e participação na vida pública, que, sem se utilizarem da expressão ação afirmativa, claramente correspondem ao que ela significa. Na mesma linha, a própria Declaração já assinala, no capítulo das “vítimas” em geral, a necessidade de adoção de "medidas afirmativas ou medidas especiais” para promover a plena integração dessas pessoas e grupos discriminados na sociedade, ilustrando a recomendação com a proposta de 
“... medidas especiais para lograr representação apropriada nas instituições de ensino, na moradia, nos partidos políticos, nos parlamentos e no emprego, em particular em órgãos judiciais e policiais, no exército e outros serviços civis, o que, em alguns casos pode exigir reformas eleitorais, reformas agrárias e campanhas em prol da participação eqüitativa” (artigo 108).”

Em paralelo às atenções prioritárias acordadas aos africanos e afrodescendentes, aos asiáticos e seus descendentes no exterior, aos povos e indivíduos indígenas, a Declaração de Durban foi o primeiro documento do gênero a reconhecer "com profunda preocupação as atuais manifestações de racismo" e violência contra os romanis/gitanos/sinti ou nômades (Travellers) - todas elas auto-denominações de diferentes comunidades antes agrupadas sob o nome genérico, hoje considerado pejorativo, de "ciganos" - e a conseqüente necessidade de se elaborarem políticas e mecanismos que os protejam. Por motivos apontados anteriormente, não foi possível à Conferência de Durban tratar do problema das castas e das discriminações impostas aos párias ou dalits intocáveis, de acordo com tradições religiosas ou não. É, por outro lado, incontestável que Durban, de conformidade com as intenções originais que embasaram a proposta da Conferência desde 1994, deu atenção adequada à xenofobia como um dos mais graves problemas da atualidade mundial. Em seu artigo 16, a Declaração diz:

"16. Reconhecemos que a xenofobia contra os não-nacionais, em particular os migrantes, os refugiados e os solicitantes de asilo, constitui uma das principais fontes do racismo contemporâneo, e que as violações de direitos humanos cometidas contra membros desses grupos ocorrem largamente no contexto de práticas discriminatórias, xenófobas e racistas.

Conseqüentemente, as recomendações de medidas feitas aos Estados, no Programa de Ação, para combater discriminações simples ou agravadas contra trabalhadores migrantes, refugiados e outros estrangeiros que se encontrem legal ou ilegalmente na respectiva jurisdição é pormenorizada, estendendo-se por muitos parágrafos.

Outros assuntos atuais que também estiveram na base das motivações originais da proposta da Conferência na Subcomissão contêm-se nos seguintes parágrafos transcritos a título exemplificativo:

“27. Expressamos nossa preocupação com o fato de que, além de o racismo vir ganhando terreno, formas e manifestações contemporâneas de racismo e xenofobia estão tentando voltar a adquirir reconhecimento político, moral e até legal de muitas maneiras, inclusive por intermédio das plataformas de algumas organizações e partidos políticos, e da disseminação por meio de tecnologias modernas de idéias baseadas no conceito de superioridade racial. 
83. Ressaltamos o papel chave que os líderes e partidos políticos podem e devem desempenhar na luta contra o racismo, a discriminação racial, a xenofobia e a intolerância correlata, e encorajamos os partidos políticos a tomarem medidas concretas para promover solidariedade, tolerância e respeito.

84. Condenamos a persistência e o reaparecimento do neonazismo, do neofascismo e das ideologias violentas baseadas em preconceitos raciais ou nacionais, e declaramos que esses fenômenos não se podem justificar em qualquer caso, nem em qualquer circunstância.”

Não cabe aqui uma análise aprofundada de como a globalização econômica sem orientação social ou contrapesos para seus "efeitos colaterais", tem sido responsável pelo ressurgimento de fundamentalismos religiosos, étnicos, raciais e nacionais. A literatura sobre a matéria é convincente e abundante. De qualquer forma, ainda que alguém queira negar essa responsabilidade, até porque, realmente, ninguém soube ainda indicar maneiras de corrigi-la sem regressar a fórmulas ultrapassadas, ninguém tampouco poderá negar que a globalização é o pano de fundo em que emergem todos esses "casos" e "circunstâncias", aludidos no Artigo 84. É importante que a Conferência de Durban não tenha evadido a questão, caso contrário somente abordaria sintomas. Fê-lo, aliás, bem no início, em seu longo Artigo 11, onde diz, entre outras frases:

“... Embora a globalização ofereça grandes oportunidades, no presente seus benefícios se distribuem de forma muito desigual, como também o são seus custos. (...) Esses efeitos (da globalização) podem agravar inter alia a pobreza, o subdesenvolvimento, a marginalização, a exclusão social, a homogeneização cultural e as desigualdades econômicas que podem ocorrer na base de linhas raciais, dentro dos Estados e entre eles, com conseqüências negativas. (...) Somente desenvolvendo esforços amplos e sustentados para criar um futuro comum, fundamentado em nossa comum humanidade em toda sua diversidade, poder-seá produzir uma globalização plenamente includente e eqüitativa.”

Com o mesmo tipo de preocupação estrutural voltada para a realidade presente, o artigo 18 ressalta que:

“... a pobreza, o subdesenvolvimento, a marginalização, a exclusão social e as disparidades econômicas estão estreitamente vinculadas ao racismo, à discriminação racial, à xenofobia e à intolerância correlata e contribuem para a persistência de atitudes e práticas racistas que, por sua vez, geram mais pobreza”.

Partindo do geral para o específico, o artigo 74 da Declaração trata do trabalho infantil, muito falado atualmente e quase sempre condenado, pela ótica dos direitos humanos, com um simplismo contraproducente - como se tal trabalho 
decorresse apenas da ambição exploradora dos pais, ou dos respectivos governos. Contrariando essa linha, o texto em questão se mostra, com linguagem comedida, bastante arguto:

“74. Reconhecemos que o trabalho infantil está relacionado com a pobreza, a falta de desenvolvimento e condições socio-econômicas correlatas e que, em alguns casos, poderia perpetuar a pobreza e a discriminação racial por privar de maneira desproporcional as crianças dos grupos afetados da possibilidade de adquirir as aptidões humanas necessárias a uma vida produtiva e para beneficiar-se do crescimento econômico".

É pouco, sem dúvida, e cheio de precauções sem sentido para mentes que conhecem de perto o problema, às vezes na própria pele. Mas é o máximo que já se disse sobre um fenômeno crescente, cujas raízes profundas violam muito de frente o credo neoliberal vigente na globalização sem controles.

\section{Avaliação e conclusão}

Em artigo publicado ainda antes do encerramento da Conferência, o jornalista Bob Herbert, como que para justificar a saída antecipada da delegação oficial norte-americana, dizia, no New York Times, que o encontro de Durban estava fadado à irrelevância desde sua concepção, porque os problemas da intolerância étnica, religiosa e de gênero são "grandes e complexos demais para serem tratados por uma Conferência da ONU”. Não fosse o autor geralmente perspicaz e construtivo na análise dos problemas raciais dos Estados Unidos, e se lhe deveria perguntar: Se não a ONU, quem? Mas a complementação do mesmo artigo explicitava um pouco mais as razões de sua descrença: os organizadores podem ter tido os motivos mais elevados, mas "não se pode lançar uma luta global contra o racismo a partir de uma base de má fé e hipocrisia”. ${ }^{26}$

Os críticos à Conferência de Durban são muitos, de natureza e níveis variados. Mas não é factível apontar um único país ou grupo de países como responsável exclusivo pelas provocações e falhas ocorridas. Nem faz sentido observar somente as limitações e insucessos do evento, sem registrar os pontos positivos que ele também comportou.

$\mathrm{Na}$ esfera dos Estados, conforme aqui explicado, os governos que se opunham à reunião pouco fizeram para que ela se concretizasse. Quando a Conferência foi, afinal, aprovada pela Assembléia Geral da ONU, tornando-se irreversível, tampouco se decidiram a encará-la de maneira construtiva. Os que a favoreciam porque tinham reivindicações concretas para fazer não se mostravam dispostos a concessões que levassem a resultados úteis. Era um círculo vicioso que quase tecia um nó górdio. ${ }^{27}$ 
É curioso notar como, ao contrário do que se observou no Brasil, onde os preparativos foram intensos, envolvendo entusiasticamente o Governo e a sociedade civil (inclusive numa Conferência Nacional que adiantou pontos importantes depois refletidos nos documentos de Durban e adotados pelo Governo), no país que historicamente mais inspirou em todo o mundo movimentos pelos “direitos civis”, as ONGs, a imprensa e até mesmo a Academia quase não deram atenção ao evento. Quinze dias antes de seu início, em seminário sobre o "Racismo nos Estados Unidos e no Brasil” realizado na Universidade de Sacramento, Califórnia, com copatrocínio da Universidade da Bahia, os afro-norte-americanos presentes, ao contrário dos brasileiros, não pareciam sequer saber que um encontro mundial contra a discriminação racial estava prestes a iniciar-se, sob o patrocínio das Nações Unidas, na terra de Nelson Mandela. ${ }^{28}$ Ainda assim, ademais dos 2.300 delegados oficiais de 163 países, sendo 16 Chefes de Estado ou de Governo, 58 Ministros de Relações Exteriores e 44 Ministros de outras pastas, quase 4.000 representantes de organizações não-governamentais e 1.100 jornalistas foram registrados pela ONU em Durban. Sem falar dos eventos paralelos havidos antes e durante a Conferência, relacionados no Relatório à Assembléia Geral ${ }^{29}$ (somente o Fórum de ONGs contou com 8.000 participantes, em representação de 3.000 organizações não-governamentais de todos os continentes), parece legítimo dizer que um encontro de tais proporções pode ter sido tudo, menos irrelevante. A mobilização que causou é per se uma forma de conscientização, quando por mais não seja, pelo efeito demonstração.

De todas as críticas conhecidas à Conferência de Durban, a que mais surpreendeu o autor destas linhas veio de Michael Banton, professor de sociologia em Bristol e ex-membro do Comitê para a Eliminação da Discriminação Racial ou CERD (treaty body que monitora a implementação da Convenção Internacional sobre a Eliminação de Todas as Formas de Discriminação Racial), ${ }^{30}$ precisamente porque ele, com a experiência que tem e a respeitabilidade de que goza, não tinha o direito de ser tão ingênuo, nem tão negativista. Diz Michael Banton que, "se a primeira conferência mundial foi um desastre, a terceira foi uma calamidade que feriu a reputação da ONU e as atitudes em favor da cooperação internacional”. ${ }^{31}$ Além de repetir algumas das objeções mais óbvias veiculadas por países ocidentais às posturas árabes sobre o Oriente Médio - as quais, como já visto, não foram incorporadas aos documentos com sua virulência original -, grande parte de suas repreensões dizem respeito ao fato de "a Conferência” não ter optado por cobrar dos países o cumprimento das obrigações que assumem ao aderirem à Convenção sobre a Eliminação de Todas as Formas de Discriminação Racial, e ao fato de "a Conferência” não ter dado maior valor à atuação do CERD, inclusive no que diz respeito à questão das reparações - como se a Conferência fosse uma entidade autônoma, capaz de tomar decisões independentes da vontade de seus 
participantes. ${ }^{32}$ Pior ainda, Banton não quer reconhecer o óbvio de que "calamidade" não foi a Conferência em si, mas “a circunstância” em que ela se realizou.

A verdade é que Durban foi a melhor conferência que se poderia realizar sobre temas tão abrangentes, em condições tão adversas, numa situação internacional que, em adição à doxa econômica neoliberal (para falar com Bourdieu) avessa a preocupações sociais, já se mostrava cada dia menos favorável ao multilateralismo e à diplomacia parlamentar. O simples fato de ela ter tido seus documentos finais adotados sem voto (a votação havida, é sempre bom relembrar, foi para rejeitar a reapresentação extemporânea de propostas superadas) representa, como já dito, um progresso com relação às conferências de 1978 e 1983. Muito mais do que isso, porém, os documentos de Durban trazem novos conceitos e compromissos importantes, particularmente para o combate ao racismo estrutural. Estes podem ser utilizados como guias à atuação dos Estados, internamente e em ações internacionais, ou como instrumento semi-jurídico para cobranças das sociedades ao governos.

Nenhuma conferência resolve por ela mesma os problemas que se dispõe abordar. O máximo que pode fazer é sugerir caminhos para que possamos "salvar nossa circunstância”. Como ensina Ortega y Gasset, se não salvamos a ela, não salvamos a nós mesmos.

Conforme terá ficado aqui abundantemente demonstrado, as responsabilidades pelos problemas verificados em Durban são de diversos atores. A responsabilidade pela implementação da maioria das recomendações - como aquelas concernentes à "medidas afirmativas” que começaram a ser aplicadas no Brasil depois dessa Conferência - dependerá, por sua vez, como é o caso de qualquer documento emergente de encontro multilateral, da seriedade com que cada Estado encara as decisões coletivas de que tenha participado (e, com exceção de Israel e dos Estados Unidos, todos foram partícipes). Dependerá também da capacidade de utilização desses documentos pela sociedade civil. Dependerá finalmente, em última e mais definitiva instância, de uma conscientização generalizada - hoje em dia praticamente impossível - de que, como diz a Declaração de Durban em artigo supracitado, somente com a criação de um futuro de condições mais equânimes, "baseado em nossa comum humanidade em toda sua diversidade”, a globalização poderá ter efeitos antidiscriminatórios.

Novembro de 2002

\section{Notas}

1968: o ano que não terminou - a aventura de uma geração. Rio de Janeiro: Nova Fronteira, 1988. Votaram contra, previsivelmente, os Estados Unidos e Israel, que se haviam retirado da conferência; abstiveram-se, surpreendentemente, a Austrália e o Canadá.

3 Hoje Subcomissão para a Promoção e Proteção dos Direitos Humanos. 
4 Apenas o perito egícpio Ahmed Khalifa deixou de co-patrociná-la (ou seja, de se incluir na lista de co-autores), sem explicação inteligível, mas evidentemente a apoiou sem hesitações.

5 Para um exame das grandes conferências da década de 90 v. ALVES, José Augusto Lindgren. Relações internacionais e temas sociais - A década das conferências. Brasília: FUNAG e IBRI, 2001.

6 A Conferência de 1978 havia sido prevista no programa de ação da Primeira Década de Combate ao Racismo e à Discriminação Racial, iniciada em 1973, conforme a Resolução 3057 (XXVIII), adotada pela Assembléia Geral da ONU em 2 de novembro de 1972. A Segunda Conferência, de 1983, foi convocada pela Resolução 35/33, de 14 de novembro de 1980, com o objetivo de avaliar as atividades da Primeira Década.

7 Originada da Cúpula do Movimento dos Não-Alinhados de Argel, em 1973, essa formulação do sionismo como uma forma de racismo foi repetida em resoluções e outros documentos da ONU por quase vinte anos, tendo sido incluída até mesmo no programa adotado na Conferência de Copenhague sobre a Mulher de 1980 (v. JACKSON, Richard L. The Non-Aligned, the U.N. and the Superpowers, Nova York: Praeger, 1983, p 172, 175-77).

8 Para um exame do assunto, com citação de autores, v. ALVES, J. A. Lindgren. No peito e na raça - A americanização do Brasil e a brasilianização da América. Impulso - Revista de Ciências Sociais e Humanas. Piracicaba, UNIMEP, vol. 12, n. 27, p. 91-106, 2000, e Cidadania e Justiça. Associação de Magistrados Brasileiros. Rio de Janeiro, ano 5, n.11, p. 110-128, $2^{\circ}$ semestre de 2001.

9 A referência a "outras formas contemporâneas correlatas de intolerância” (other related contemporary forms of intolerance) foi usada por mim no título original da Conferência para cobrir determinados tipos de intolerância e discriminação muito em voga naquela época, persistentes até hoje, que não se enquadravam claramente na definição legal da discriminação racial. Pensava eu, sobretudo nos conflitos da Bósnia-Herzagovina, onde, além de se tratar da mesma raça, da mesma língua e, está claro, da mesma “etnia” eslava, a “nacionalidade” bósnia havia sido inventada a partir de uma religião que sequer era praticada por todos os "muçulmanos" dessa ex-República Socialista Iugoslava pluricultural (no período de Tito, a "nacionalidade" muçulmana foi inventada, mas convivia de forma pacífica e com relações de amizade e parentesco com as comunidades ortodoxa-sérvia e católica-croata da mesma região).

V. inter alia KAHN, Túlio; PINHEIRO, Daniela Amendola. A evolução do neonazismo no Brasil. In: Núcleo de Estudos da Violência e Comissão Teotônio Vilela, Os direitos humanos no Brasil. São Paulo: USP, 1993, p. 56-63.

11 A Resolução 1994/2, cujo texto (original em inglês) tive a honra de redigir para consideração pela Subcomissão e foi aprovado em 12 de agosto de 1994, refletia, em linguagem sucinta, quase todos os fatos e tendências aqui mencionadas. Isso pode ser visto no preâmbulo, ao recordar tanto as conferências de 1978 e 1983 sobre o racismo (segundo parágrafo), como os bons resultados da Conferência de Viena de 1993 sobre os direitos humanos e a atenção por ela dedicada ao racismo (terceiro parágrafo); ao notar que "milhões de seres humanos continuam a ser vítimas de formas variadas de racismo e discriminação racial e étnica” (quarto parágrafo); ao levar em conta "a seqüência de conferências mundiais programadas pelas Nações Unidas para se realizarem antes do ano 2000” (sexto e último parágrafo preambular), para recomendar, no único parágrafo dispositivo, à Comissão dos Direitos Humanos que sugerisse, por intermédio do ECOSOC, à Assembléia Geral a "possibilidade de convocação de uma conferência mundial contra o racismo, a discriminação racial e étnica, a xenofobia e outras formas contemporâneas correlatas de intolerância, a se realizar em 1997” (a indicação de 1997 visava a aproveitar o élan das conferências já programadas, anuais desde a Rio-92 até a Habitat-II, de Istambul, em 1996; a menção nominal à discriminação étnica, já subentendida na definição do Artigo $1^{\circ}$ da Convenção de 1965, era motivada pelas várias limpezas étnicas em curso, denunciadas então sobretudo na 
ex-Iugoslávia; a inclusão da xenofobia no título era uma maneira de garantir que o evento trataria de um dos fenômenos que mais se vinham agravando em decorrência da globalização econômica).

12 Sobre essa tendência do mundo desenvolvido, na fase imediata ao fim da Guerra Fria, de atribuir todas as mazelas do planeta aos pobres, v. inter alia meu já citado Relações internacionais e temas sociais - A década das Conferências, p.59-61.

13 V. supra nota 8. As duas primeiras conferências chamavam-se simplesmente "Conferência Mundial de Combate ao Racismo e à Discriminação Racial” e "Segunda Conferência Mundial ... (idem)".

14 Extraio estes dados factuais - não a interpretação - de BANTON, Michael. Lessons from the 2001 World Conference Against Racism. Journal of Ethnic and Migration Studies, vol. 28, $\mathrm{n}^{\circ} 2$, abril de 2002.

15 Não quero com a presente crítica negar as violações de direitos humanos pelas forças de Israel, violações condenadas pela ONU e pelo Governo brasileiro. O que soa inaceitável é a incriminação genérica de um dos lados do conflito, com argumentação errônea (ou relativização de horrores genocidas contra inocentes).

16 Para não cometer uma injustiça flagrante, não posso deixar de assinalar o extraordinário trabalho da Bélgica, na qualidade de coordenadora da União Européia, cuja paciência (irritante para os de fora), logrou manter os quinze unidos e presentes até o final do evento. Foi também a Bélgica, na pessoa do Professor Marc Bossuyt, membro do CERD (e co-patrocinador da proposta original da Conferência na Subcomissão), quem presidiu com proficiência e dedicação o Grupo de Trabalho negociador da Declaração.

17 A terceira sessão do Comitê Preparatório (em Genebra de 30 de julho a 10 de agosto), não prevista nas resoluções sobre a Conferência, foi decidida exatamente em função da massa de discordâncias, que as duas sessões anteriores não haviam conseguido aplainar (a segunda sessão ocorreu de 21 de maio a $1^{\circ}$ de junho de 2001). Mas isso não chegava a ser novidade, nem a significar dificuldades intransponíveis, na medida em que a Conferência de Viena de 1993 teve algo de assemelhado, senão pior, no processo preparatório (v. ALVES, José Augusto Lindgren. Relações internacionais e temas sociais - A década das conferências, p. 92)

18 Documento das Nações Unidas A/CONF.189/1/Rev.1, de 2 de setembro de 2001. A palavra “compensatória” foi mantida entre colchetes, indicativos da falta de consenso, até a adoção da Agenda pela Conferência, no dia 31 de agosto de 2001.

19 A Declaração e o Programa de Ação de Durban constam do Relatório da Conferência Mundial contra o Racismo, a Discriminação Racial, a Xenofobia e Intolerância Correlata, documento das Nações Unidas A/CONF.189/12. As citações aqui feitas foram traduzidas por mim dos textos em inglês e em espanhol.

20 Note-se que sequer o termo “gênero” (de conotação sociológica, ao contrário de “sexo”, meramente biológico), postulado pelo movimento de mulheres e previamente usado nos documentos de Pequim, foi aceito. Para esclarecer quaisquer dúvidas, nas poucas vezes em que a palavra aparece, como no trigésimo terceiro parágrafo preambular (que reitera a conveniência de se aplicar uma perspectiva de gênero para evitar discriminações contra a mulher), uma nota de rodapé explicita referir-se o termo “a ambos os sexos, varão e mulher, no contexto da sociedade”, não comportando qualquer outro significado.

21 Para uma descrição do racismo científico e sua evolução para o "novo racismo" atual, v. WIEWIORKA, Michel. Le racisme, une introduction. Paris: La Decouverte, 1998. Sobre o "novo racismo europeu", v. o mesmo WIEWIORKA, Michel et al. Racisme et xénophobie en Europe - une comparaison internationale. Paris: La Découverte, 1994.

22 O Chefe titular da delegação do Brasil foi o então-Ministro da Justiça José Gregori, que proferiu a alocução oficial em Plenário. O Embaixador Sabóia exercia, na época, as funções de Secretário de Estado para os Direitos Humanos. Abrigando grande número de autoridades e representantes dos três Poderes em níveis diversos da Federação, assim como integrantes de movimentos da 
sociedade civil, a delegação do Brasil em Durban foi uma das mais numerosas. A ela se associavam mais de 200 militantes, que compareceram ao fórum de ONGs, ao lado do Centro de Conferências, e mantinham com a delegação oficial interação constante, notavelmente cooperativa. É de notar, também, que a Relatoria Geral da Conferência coube, por eleição, a uma brasileira, muito atuante na sociedade civil: Edna Roland.

23 Documentos A/CONF.189/4 e A/CONF.189/5.

24 Não posso deixar de assinalar, até por impulso patriótico, que foi duas vezes graças ao Brasil, e pela mesma pessoa, o Embaixador Gilberto Sabóia, que a Conferência de Durban teve êxito: ao coordenar as discussões e, conseqüentemente, a redação dos parágrafos alternativos importantíssimos sobre as chamadas questões do passado, assim como pela "ousadia” de formular sozinho a moção procedimental de não-consideração para os parágrafos inaceitáveis concernentes ao Oriente Médio. E é sempre bom recordar que também o Brasil, na mesma pessoa do Embaixador Gilberto Sabóia, já havia sido responsável em 1993 pela redação consensual da Declaração e Programa de Ação de Viena, na Conferência Mundial sobre Direitos Humanos. Todas as declarações e manifestações de reservas se acham reproduzidas no relatório da Conferência à Assembléia Geral - o já citado documento A/CONF. 189/12.

26 HERBERT, Bob. Doomed to Irrelevance. The New York Times. New York, 06 set. 2002.

27 Infelizmente o nó se apertou ainda mais depois da Conferência, pelo maximalismo extremado de uns e pela inflexibilidade de outros, na seqüência que teve o tema na Comissão dos Direitos Humanos das Nações Unidas, na sessão de 2002 (os ocidentais votaram em bloco contra a resolução sobre o assunto).

28 Notei isso, estarrecido, porque, então na qualidade de Cônsul Geral do Brasil em S. Francisco, fui convidado a participar do seminário e aceitei. Por seus organizadores e outros militantes negros norte-americanos soube posteriormente que grande parte do "movimento negro" do país não tinha interesse na conferência porque ela tornaria evidente suas cisões internas, inclusive nas posições adotadas sobre as ações afirmativas. Talvez por isso o Governo tenha tido a possibilidade de retirar-se de Durban sem repercussões críticas maiores na opinião pública doméstica.

29 V nota 20 supra.

30 Para uma breve visão do que é o CERD e do trabalho que realiza, v. ALVES, José Augusto Lindgren. Racismo e direitos humanos: a $60^{\text {a }}$ sessão do CERD. Carta Internacional. São Paulo, USP/FUNAG, ano X, n. 111, p.19, maio de 2002.

31 BANTON, Michael. Op. cit., p. 360.

32 Além disso, o CERD é objeto específico de dois importantes parágrafos do Programa de Ação, os de números 177 e 178, destinados a fortalecer o Comitê, além de o ser indiretamente na infinidade de outras recomendações e artigos que, desde o Preâmbulo da Declaração, assinalam a importância da adesão de todos os Estados à Convenção de 1965 e de sua plena implementação.

\section{Resumo}

O presente trabalho teve por objetivo estudar a Conferência de Durban contra o Racismo ocorrida em 2001. Buscou-se analisar o contexto em que a Conferência ocorreu, as dificuldades encontradas como a não participação do governo de Washington e Tel-Aviv, os avanços alcançados e, ao final, o importante papel exercido pelo Brasil. 


\section{Abstract}

The present article had the aim of studying the Durban Conference against Racism that took place in 2001. The context in which the Conference ocurred, the dificulties that were found like the non-participation of the Washington and TelAviv governments, the improvements and, at the end, the important role that was played by Brazil, were analyzed in this article

Palavras-chave: Conferência de Durban; Racismo; Discriminação Racial. Key words: Durban Conference; Racism; Racial Discrimination. 